\title{
A Novel Approach for the Production of Iron Powders by Radiation of Microwave
}

by Hitoshi SAKAI ${ }^{1}$, Takayuki JINNO ${ }^{1}$ and Ryuzou TAKEDA ${ }^{1}$

1. Dowa Iron Powder Co., Ltd., Chikkousakaemachi, Okayama 702

\begin{abstract}
The carbothermic reduction of iron ores, including hematite and mill scale, using coal char and limestone was studied under microwave radiation for the development of a novel technique to produce iron powders. Besides coal char, the usability of cokes and Hongei coal was also examined. The principal findings are as follows:

(1) Reduction rate of mill scale with coal char increases with an increase in the amount of coal char. The percent reduction after 10 minutes radiation of microwave increases linearly with an increase in coal char amount when the range of equivalent ratio of coal char to mill scale is less than 4 . A further increase in coal char amount, however, was less significant to enhance the reduction.

(2) The percent reduction of mill scale-hematite mixture when the content of mill scale is below $40 \mathrm{wt} \%$ can be calculated from the additivity rule. In contrast, the percent reduction of the mixture containing more mill scale is always higher than that expected.

(3) When the sized fraction of carbon staffs of $-32+80$ mesh was used for the carbothermic reduction of mill scale-hematite mixture, coal char was most efficient amount three carbon staffs examined, while cokes was most inefficient. However with the ground product of cokes of -325 mesh, the reduction of mill scale was greatly improved. Thus the mixed use of suitably ground cokes and coal char and the use of ground cokes in an open atmosphere are useful to proceed reduction quickly enough.

(4) Recycled use of carbon staff was found to be useful to promise a large reduction efficiency, providing a better recovery of iron powders. Judging from these findings, it is considered that the producing process of iron powder under microwave radiation must be economical and productive way when a suitable microwave oven is once designed.
\end{abstract}

KEY WORDS: Microwave, Carbothermic Reaction, Hematite, Mill Scale, Iron Powder

\section{1. はじめに}

著者らの工場では従来よりトンネルキルン還元法による鉄粉の 製造を行っているが，この方法では鉄鉱石の還元時の吸熱反応の 熱量の一部を, 還元剤である炭素の燃焼に依存しているのが現状 であり, 容器であるサガーの余熱時間を含めると炬内での滞留時 間は 4 日間にも達しェネルギー効率の面からも, また生産性の面 からも決して効率の良い方法とはいい難い。

次報 ${ }^{1)}$ において指摘するようにマイクロ波照射下での炭素還元 反応は, 鉄粉製造に関しても新しい夢を与え得る方法と考えられ るが，しかし，これまでこのような試みに対して行われた研究例 はきわめて少ない ${ }^{2)-4)}$ 。そこで著者らはへマタイトおよびミルス

* 1992 年 10 月 21 日受付 1993 年 3 月 2 日受理

1. 正会員 同和鉄粉工業 (株)

2. 同和鉄粉工業 (株)

キーワード：マイクロ波，炭熱反応，へマタイト，ミルスケール，鉄粉
ケールを原料とする鉄粉製造法についての基礎的な知見を得る目 的で，まず家庭用電子オーブンを若干改良した装置を用いて基礎 実験を行った。 本報告は得られた結果をとりまとめたものである。

\section{2. 実 験 方 法}

\section{$2 \cdot 1$ 実験装置および方法}

マイクロ波照射還元装置としては内田製作所製の出力 $500 \mathrm{~W}$, 周波数 2. $45 \mathrm{GHz}$ の CORONA DR-511型電子オーブンを改造に 用いた。すなわちオーブンの底部に試料用るつぼの載物位置をマ ークした磁製板（厚さ $11 \mathrm{~mm}$ ) を置き, また温度測定のため, オー ブン上部に穴をうがち磁製管を上記磁性板上に載せたるつぼ内側 の底より $7 \mathrm{~mm}$ の位置まで挿入したものである。温度測定は上記磁 製管の底部の温度をチノー社製 IR-FBS 型ファイバー式放射温度 計を用いて行った。還元実験では特に断らない限り内容積 $30 \mathrm{~m} l$ の磁製るつぼ内にへマタイトまたはミルスケールあるいは両者の 
混合物 $10 \mathrm{~g}$ と適当な炭素源 $5 \mathrm{~g}$ および石灰石 $1 \mathrm{~g}$ とをよく混合して 入れ，上部を平らにならした後，Fig.1に示すような放熱防止方法 を施して実験を行った。炭酸カルシウムの添加は, その熱分解に よって生じた $\mathrm{CO}_{2}$ がカーボンと反応して CO 濃度を高めるのに効
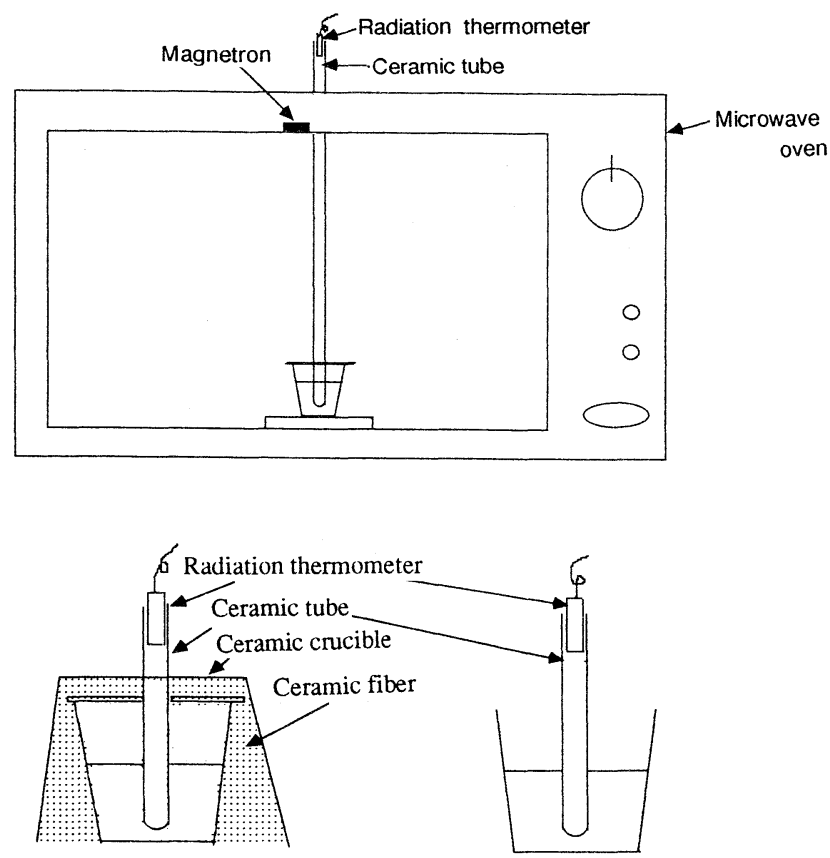

(a)

(b)

Fig. 1 Schematic illustration of general view and partial view of methods of sample holding under the radiation of microwave.

Table 1 Chemical composition of raw iron ores.

\begin{tabular}{c|c|c|c}
\hline \multicolumn{2}{c|}{ Mill scale } & \multicolumn{2}{c}{ Hematite } \\
\hline Element & Weight $(\%)$ & Element & Weight(\%) \\
\hline $\mathrm{Fe}_{\mathrm{t}}$ & 75.33 & $\mathrm{Fe}_{\mathrm{t}}$ & 68.13 \\
$\mathrm{Fe}_{\mathrm{m}}$ & 0 & $\mathrm{Fe} \mathrm{m}^{2}$ & 0 \\
$\mathrm{~S}$ & 0.005 & $\mathrm{~S}$ & 0.004 \\
$\mathrm{C}$ & 0.06 & $\mathrm{C}$ & 0.05 \\
$\mathrm{P}$ & 0.008 & $\mathrm{P}$ & 0.025 \\
$\mathrm{SiO}{ }_{2}$ & 0.04 & $\mathrm{SiO}$ & 0.6 \\
$\mathrm{Mn}$ & 0.21 & $\mathrm{Mn}$ & 0.02 \\
$\mathrm{Cu}$ & 0.007 & $\mathrm{Cu}$ & 0.001 \\
$\mathrm{Sn}$ & 0.001 & $\mathrm{Sn}$ & 0.001 \\
\hline
\end{tabular}

Fe ${ }_{\mathrm{t}}$ : Total $\mathrm{Fe} \quad \mathrm{Fe}_{\mathrm{m}}$ : Metallic $\mathrm{Fe}$
果があることによる。マイクロ波の照射は特に断らない場合には 10 分間の一定とした ${ }^{a}$ 。

\section{$2 \cdot 2$ 供試試料}

鉄鉱石としてはインド国 Bailadila鉱山産の粒度-60mesh の ヘマタイトならびに粒度 -32 mesh のミルスケールの 2 種類を用 いた。供試鉄鉱石の化学分析値をTable 1 に示す。いずれの試料 も極めて純度の高いものであるが，ミルスケールは組成的には, $\mathrm{Fe}_{3} \mathrm{O}_{4}$ に相当するものである。 $\mathrm{McGi} 11$ らは各種鉱物のマイクロ 波に対する吸収性について論じ，マグネタイトはへマタイトより

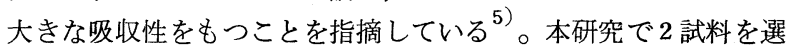
んだのは還元速度にどのような影響がみられるかについて検討す るためである。

一方, 炭素源としては, Table 2 に示すような組成のチャ一炭, コークスおよびホンゲイ炭の 3 種類について, それらの適用性を 検討した。比較の目的にはいずれの炭素材についても-32+80 mesh に整粒したものを鉱石および石灰石とよく混ぜて用いた。 しかし通常の還元実験においては特に断らない限り, 粒度一16 mesh のチャー炭を用いた。さらに供試石灰石は足立鉱山産の -48 meshの高純度のものである。

これら供試試料の粒度分布をTable 3に示す。なおコークスに ついての実験では，これから-32+80 mesh，-150+200 mesh お よび-325 mesh フラックションを採取し，粒度の影響を検討する 実験に用いた。また後述するように -325 mesh のコークスを用い た場合には大きい還元速度が得られるが, Fig.1(a)の保持方法で は粒成長をおこし, 鉄粉製造という目的に対して適さないことが 分かった。しかし炭素材の価格の点ではチャ一炭に比べるとコー クスはかなり安価であり, 経済的にはその使用が望まれる。そこ で,チャー炭(粒度-16mesh) と-325 mesh に粉砕したュークス とを所定割合に混合し，還元実験に供する実験，ならびに， -325 meshのコークスを用いてFig.1 (b)のように放熱防止を施さず開 放系での還元実験も行った。

\section{$2 \cdot 3$ 分析}

マイクロ波照射を終えた後の供試試料は温度が高く，そのまま 放置すると再酸化するので $\mathrm{N}_{2}$ ガスを吹き込み急速に冷却し, 室温 に到達した後, るつぼから取り出し，ハンドマグネットで磁着分 と非磁着分に分離後, 磁着分中の金属鉄を化学分析した。この分 析值から(1)式のように, 還元により生成された金属鉄 $\mathrm{Fe}_{\mathrm{m}}$ と原鉱 Table 2 Chemical analyses of various carbon staffs used.

\begin{tabular}{c|c|c|c}
\hline \multirow{2}{*}{ Carbon } & \multicolumn{3}{|c}{ Composition (\%) } \\
\cline { 2 - 4 } & Fixed carbon & Ash & Volatile matter \\
\hline Coal char & 88.2 & 3.57 & 8.23 \\
Cokes & 87.91 & 11.1 & 0.99 \\
Hongei coal & 86.24 & 5.25 & 8.51 \\
\hline
\end{tabular}

Table 3 Particle size distribution of raw iron ores, carbon staffs and limestone used.

\begin{tabular}{|c|c|c|c|c|c|c|c|}
\hline \multirow{2}{*}{$\begin{array}{c}\text { Particle size } \\
\text { (mesh) }\end{array}$} & Mill scale(-32mesh) & Hemataite(-60mesh) & Coal char(-16mesh) & Cokes $(-32+80$ mesh $)$ & Hongei coal $(-32+80 \mathrm{mesh})$ & \multirow{2}{*}{$\begin{array}{c}\text { Particle size } \\
\text { (mesh) }\end{array}$} & \multirow{2}{*}{$\begin{array}{c}\text { Limestone } \\
(\%)\end{array}$} \\
\hline & \multicolumn{5}{|c|}{ Weight (\%) } & & \\
\hline+32 & 0.1 & - & 47.6 & 1.2 & 0.2 & +28 & - \\
\hline$-32+60$ & 40.2 & - & 30.6 & 58.6 & 57.8 & $-28+48$ & 0.6 \\
\hline$-60+80$ & 29.7 & 11.6 & 9.6 & 29.8 & 24.8 & $-48+100$ & 4.6 \\
\hline$-80+150$ & 26.5 & 12.8 & 9.4 & 9.6 & 15.8 & $-100+200$ & 8.2 \\
\hline$-150+200$ & 3.0 & 10.0 & 2.0 & 0.6 & 1.0 & -200 & 86.6 \\
\hline-200 & 0.5 & 65.6 & 0.8 & 0.2 & 0.4 & & \\
\hline
\end{tabular}

a) 本研究には供試試料をペレットにすることはしなかった。ペレットにした場合，反応の進行に伴い，オーブン内で放電する現象が現れ， 生成された粒子が溶融することが観察されたためである。 
中の鉄分量 $\mathrm{Fe}_{\mathrm{t}}$ との比の百分率により還元率を算出した。

還元率 $=\left(\right.$ 磁着物中の $\mathrm{Fe}_{\mathrm{m}}$ の重量 $) \times 100 /($ 原鉱中 の $\mathrm{Fe}_{\mathrm{t}}$ の重量)

\section{3. 実験結果および考察}

\section{3・1 ヘマタイトの䠛元速度に及ぼすチャ一炭添加量の影響}

へマタイト $10 \mathrm{~g}$, 石灰石 $1 \mathrm{~g}$ の条件で一定とし，これらに加える チャ一炭量を $3 \mathrm{~g}, 5 \mathrm{~g}$ および $10 \mathrm{~g}$ の 3 段階に変化させ,へマタイト の還元率に及ぼすチャ一炭添加量の影響について検討した。測定 結果をFig. 2 に示す。この図に明らかなようにチャ一炭添加量 3 $\mathrm{g}$ の場合はへマタイトの還元反応の引き金となり得る反応系の温 度上昇に時間がかかるため, 誘導期間 (induction period) の存 在による逆 $\mathrm{S}$ 字型の速度曲線を示し, 定常状態に達してもへマタ イトの還元速度は小さい。一方, チャ一炭量 $5 \mathrm{~g}$ および10 $\mathrm{g}$ の条件 下では誘導期間は認められず，一般的にはチャ一炭量の増加とと もに還元速度は增大する傾向が認められる。

図より $50 \%$ 還元までの時間を求め, その逆数をもって平均速度 を計算し,チャ一炭量に対しプロットするとFig.3のようになる。 すなわち, $\bar{R}_{50}$ はチャ一炭添加量の増加とともにほぼ直線的に増 大する。チャ一炭添加量が約 $2.5 \mathrm{~g}$ 以下では $\bar{R}_{50}$ は 0 になるが，こ のことはこの範囲のチャ一炭添加量ではへマタイトの $50 \%$ 還元が 達成されないことを意味すると考えられる。

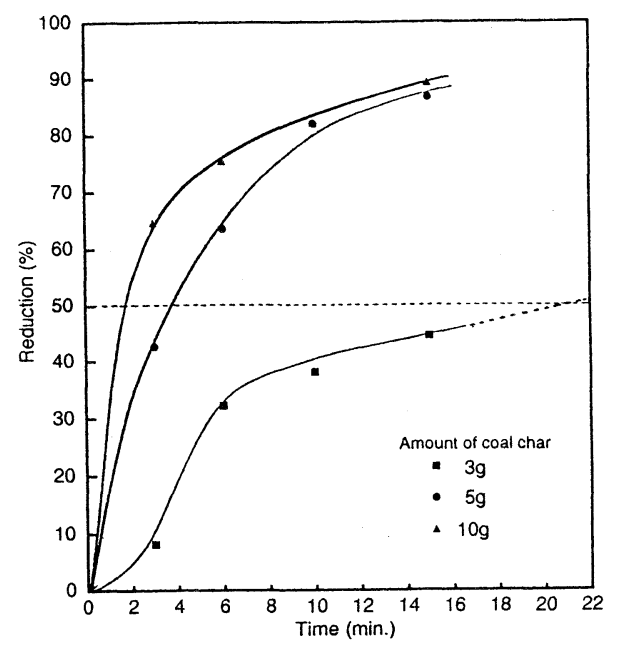

Fig. 2 Reduction rate curves for hematite using coal char as a reductant under microwave radiation.

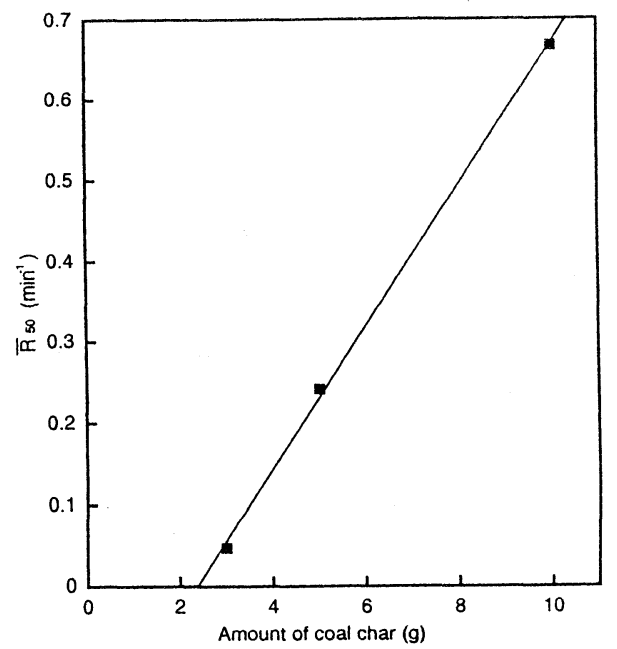

Fig. 3 Effect of coal char amount on average reduction rate $\left(\bar{R}_{50}\right)$ of hematite.
一方, Fig. 4 はチャ一炭量を変化させ, Fig.1(b)の保持法を施 しチャー炭のみをるつぼに入れたチャ一炭層の昇温速度曲線を示 す。この図に明らかなようにチャ一炭量を増すにつれ, チャー炭 層の温度上昇速度ならびに最高到達温度は増大する傾向が認めら れたが,この結果はFig. 2 およびFig. 3 に示した結果の妥当性を 指示するものである。

$$
3 \cdot 2 \text { ミルスケールの還元率に及ぼすチャ一炭添加量の影響 }
$$

Fig.2に示したへマタイトの還元速度曲線から分かるようにチャ 一炭添加量 $5 \mathrm{~g}$ および10gの条件下では, マイクロ波照射開始10分 後の還元率はその条件下における最大還元率の $85 \%$ 近くにまで到 達している。したがってマイクロ波照射時間を一定条件 (10分間) に固定し, 今後はミルスケールについての還元反応開始 10 分後の 還元率に及ぼすチャ一炭添加量の影響について検討した。測定結 果をFig.5に示す。図に明らかなようにカーボン量の増加に伴い 当量比で約 4 近傍までは還元速度はほぼ直線的に増大するが，そ れ以上チャ一炭量を増加させても, 還元速度の大きな増加はみら れずほぼ飽和状態に到達する傾向が認められる。したがって爾後 の実験ではすべて鉄鉱石 $10 \mathrm{~g}$ に対しチャ一炭添加量 $5 \mathrm{~g}$ の一定条件

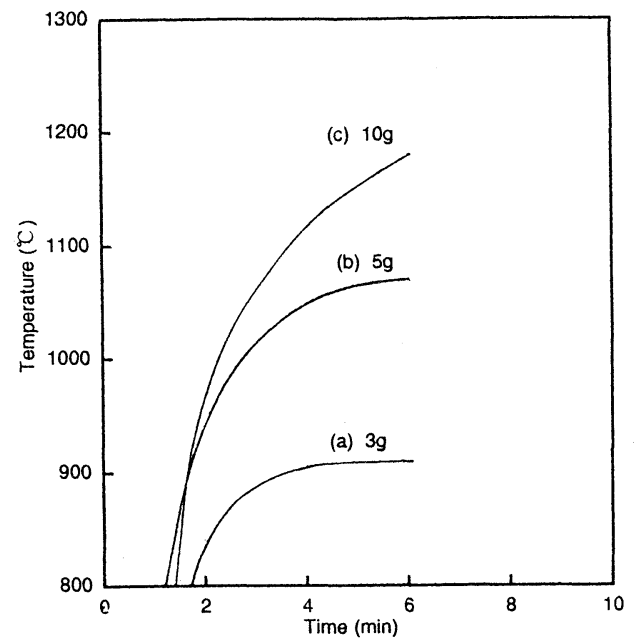

Fig. 4 Temperature variation of coal char layer under the radiation of microwave.

(Mark (a), (b), and (c) on T-time curves correspond to amount of coal char respectively.)

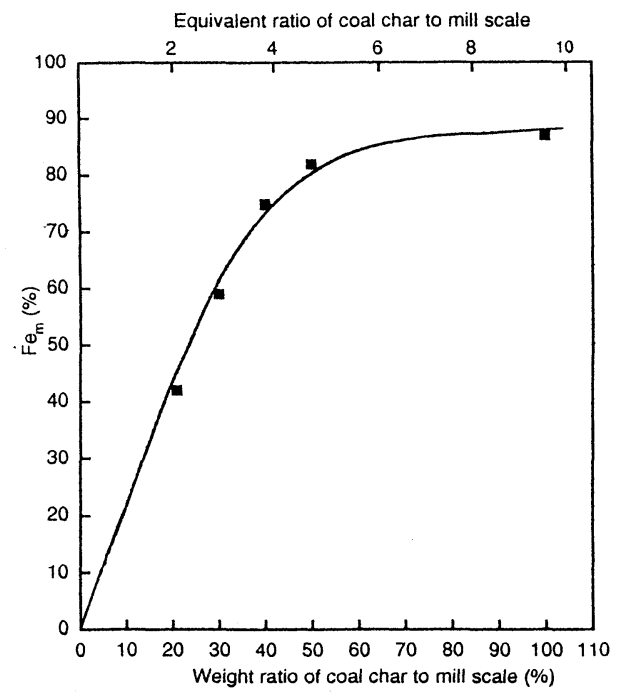

Fig. 5 Effect of weight ratio of carbon to mill scale on the $\mathrm{Fe}_{\mathrm{m}}$ of reduced product. 


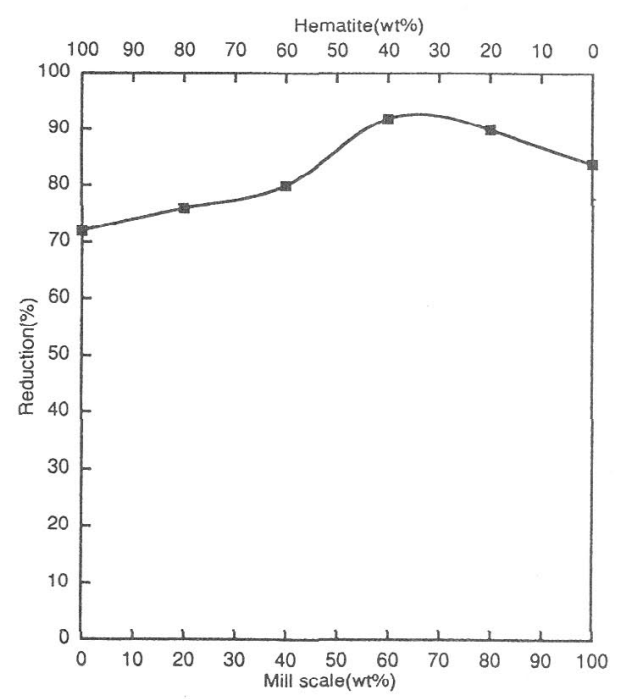

Fig. 6 Effect of weight ratio of mill scale to hematite on reduction percent.

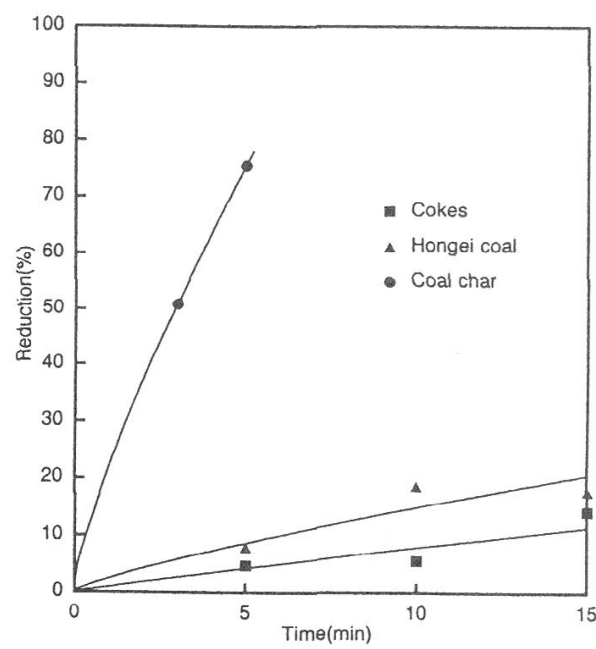

Fig. 7 Reduction rate curves of the mixture of mill scale and hematite with various carbon staffs $(-32+80$ mesh $)$.

とした。

$$
3 \cdot 3 \text { ヘマタイトとミルスケールの混合処理 }
$$

次報 ${ }^{1)}$ に述べるようにマイク口波照射条件下て鉄鉱石を炭素還 元した場合，ミルスケールの方がへマタイトに比して還元されや すいが，その差は，マイクロ波に対する両者の吸収性の差異 ${ }^{2)}$ ら予測されるよりは遥かに小さく, 系内に過剩に存在し, マイク 口波に対し最も吸収性において優れているカーボンの挙動により 支配された結果と考光るのが妥当と考察した。ミルスケールとい マタイトを混合処理する場合に，還元性において加成性が成り立 つか否かを検討することは興味がもたれる。そこで，鉄鉱石量を $10 \mathrm{~g}$ の一定としミルスケールとへマタイトの混合比を变えて還元 実験を行った。実験結果をFig.6に示す。

図に明らかなようにミルスケール添加量 $40 \%$ 以下ではミルスケ ールとへマタイトの加成性として理解できるような還元挙動をす るに対し，それ以上ミルスケールを混在させると加成性から予期 される以上の睘元率が得られた。この現象は再現性の良好なもの である。現在のところ, このように加成性以上の還元率が得られ る理由については明らかではないが，供試へマタイトとミルスケ 一ルの形状および粒度が異なり，チャ一炭との接触状態が良好に なった結果とも考えられるが，このような接触状態の定量化が容
易でない現状ではこれ以上推論を重ねることは無意味であろう。 本実験の結果をもとに，爾後の実験ではミルスケールとへマタイ

トを重量比で 60:40 とした混合物を供試した。

$3 \cdot 4$ 鉄鉱石の還元率および還元速度に及ばすカーボンの種 類および粒度の影響

以上の実験はすべて粒度-16meshのチャー炭を用いて行ったも のである。著者らの経験によれば，チャ一岸は優れた還元能をも つ炭素源であるが，高価な還元珮である。そこでチャ一炭に比し て安価な炭素源としてコークスおよびホンゲイ炭を選び，それら の還元性を比較する意味で, いずれのカーボンも $-32+80$ meshに 整粒し, 上述のミルスケールーーマタイト（重量比 60:40)の混合 物を還元した。鉄鉱石：炭素材：石灰石の混合割合はいずれの場 合も $10 \mathrm{~g}: 5 \mathrm{~g}: 1 \mathrm{~g}$ である。

実験結果をFig.7 に示す。この図にみられるようにチャ一炭で は極めて速く還元され，5 分のマイク口波照射により既に75\%の 還元率に達するのに対し，コークスを用いた場合の還元率は極め て低く, マイク口波照射15分後の還元率も，わずかに $13 \%$ であっ た。ちなみにこれら炭素材のS E M 写真はFig.8に示すように, 肉眼的にはホンゲイ炭の表面が極めて平滑性を示寸こと以外には 大さな差異が認められず，また前揭のTable2に示したようにチャ 一炭とコークスの揮発分は大きな差異はあるものの固定炭素含量 には，それほど大きな違いが認められなかった。揮発分の影響と 考えるならば踣発分含量がチャー炭とほぼ同じホンゲイ炭を用い た実験での還元速度が低いことが説明できない。Fig.9に各種炭 素材の昇温曲線を示す。これは， $-32+80$ meshに整粒した各種炭 素材10 g をそれぞれるつぼへ入れ，Fig.1(b)の保持法にさらにア

(a) Coal char

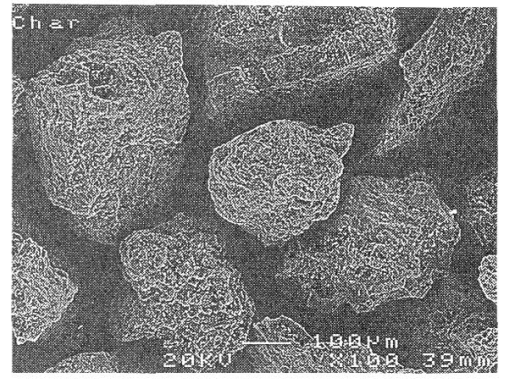

(b) Cokes

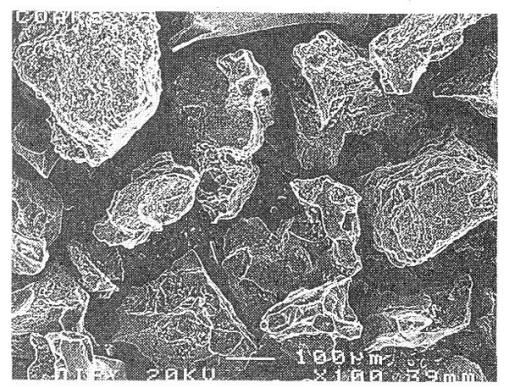

(c) Hongei coal

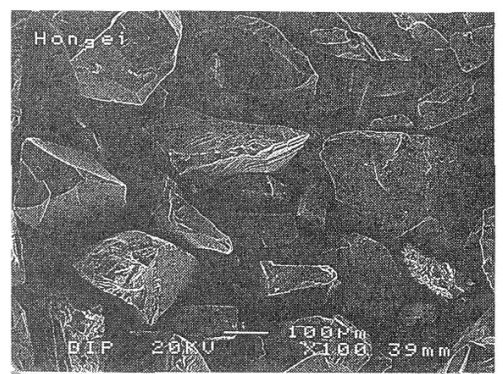

Fig. 8 SEM photographs of sized fraction $(-32+80$ mesh $)$ of various carbon staffs employed. 


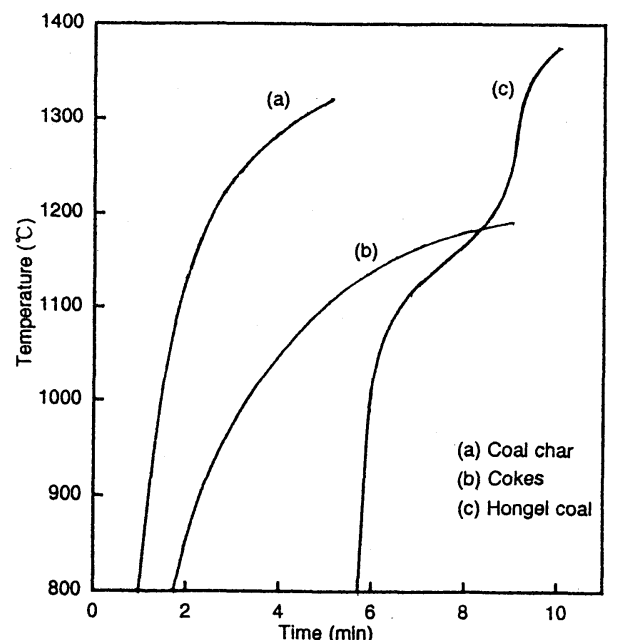

Fig. 9 Temperature elevation of various carbon staffs $(-32+80$ mesh).

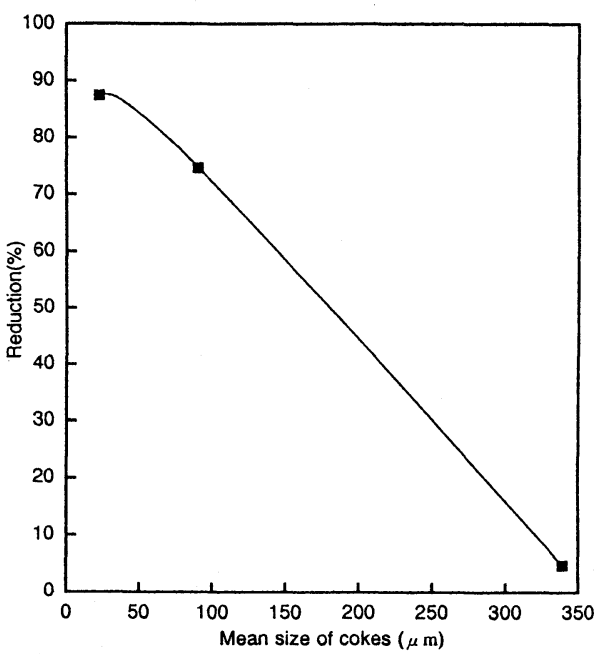

Fig. 10 Effect of particles size of cokes on the reduction rate of mill scale-hematite mixture.

ルミナるつぼをかぶせてそれぞれマイクロ波照射を行い温度測定 をしたもので，この結果をみると明らかにチャー炭の昇温が圧倒 的に速く，その結果チャ一炭を用いた還元が最も大きい還元速度 を示し，高い還元率を達成したことは容易に理解できよう。一方， コークスの昇温速度は, チャー炭のそれに次ぐものであるが, 最 高到達温度はホンゲイ炭に比して低く, その差がュークスとホン ゲイ炭を用いた場合の還元率の差として現れたと考えられる。た だし，還元性に影響を与える要因としては昇温速度以外にもあり 得ると考えられるのでそれについては今後の検討を要する。

次に，カーボンの粒度による還元速度の影響を調べるため，コ ークスの粒度の細かい試料を用いて還元実験を行った。実験結果 をFig.10に示す。図に明らかなように, 同じュークスであって も粒度が細かくなるにつれ, 還元速度は大幅に増加する傾向がみ られた。これは, コークスの粒度が細かくなると鉄鉱石とコーク スの接触が良くなり, 間隙が小さくなることにより CO の濃度が 高まることによるものと考えられる。また， $-325 \mathrm{mesh}$ 整粒した コークスでは, Fig.11に示すようにコークス層の温度はマイクロ 波10分の照射により $1,360^{\circ} \mathrm{C}$ に到達し, 得られた鉄粉も成長して 粒状になることが観察された。これに対し,Fig.11に示すように $-32+80$ mesh に整粒したコークスのみのカーボン層内の昇温速 度は-325 mesh のそれと比して遅く, 最高到達温度も低い。した がって, 昇温速度の違いも鉄鉱石の還元速度に影響を与えている

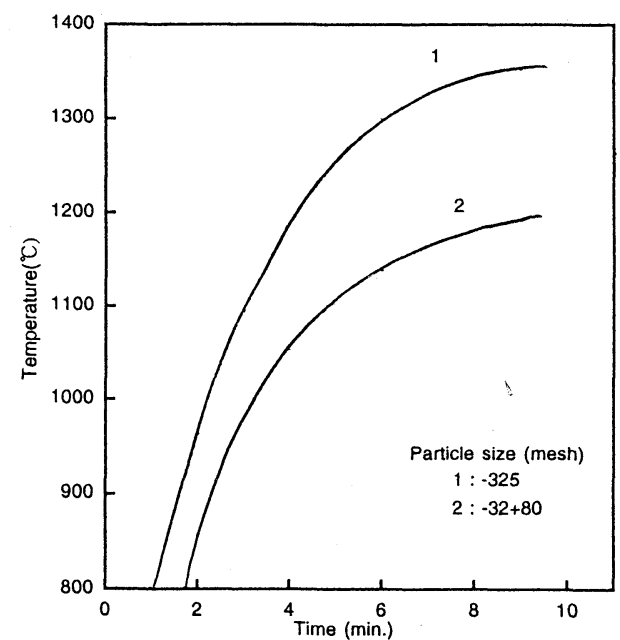

Fig. 11 Effect of particle size of cokes on temperature elevation.

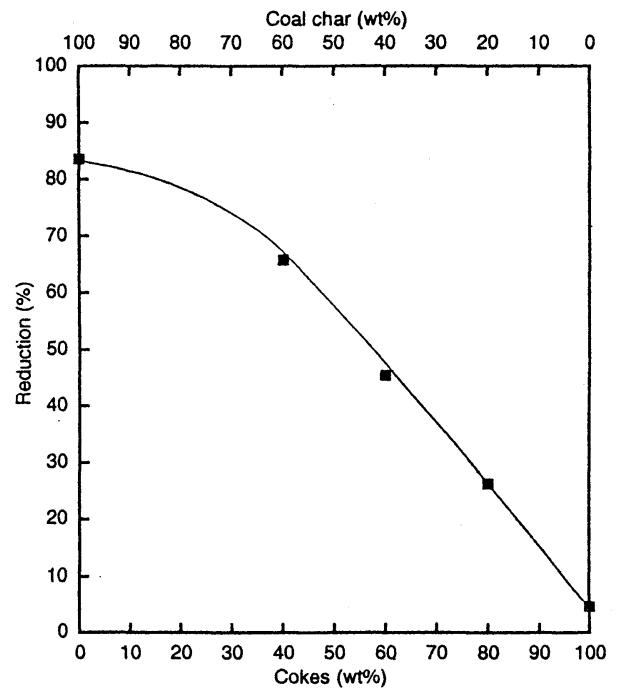

Fig. 12 Effect of mixed use of coal char ( -16 mesh) and cokes $(-32+80 \mathrm{mesh})$ on the reduction rate of mill scale-hematite mixture.

と考えられる。カーボンの揮発分の還元反応における役割につい ては，今後さらに検討を続ける必要があるが，粒度も還元速度の 大きな支配要因となっていることは本実験結果からも明らかであ る。しかしコークスの粒度が余り細かいと, 長さ $2 \sim 10 \mathrm{~mm}$ の粒状 に金属鉄が成長することは，鉄粉製造という目的に反するもので ある。上述の-325mesh に粉砕したコークスを用いる実験は，

Fig.1(a)のように放熱防止措置をとった条件下での実験結果であ る。この条件下で還元によって生成された鉄粒子の成長がみられ たことは温度が上昇し，そのために溶融が起こったことを示唆し ている。そこで，表面を被覆することなく開放したFig. 1 (b)の ような方法で, -325 mesh コークスを用いて再度還元実験を行っ た。その結果, 10 分間のマイクロ波照射で還元率は $79.4 \%, 15$ 分 間の照射では $87.2 \%$ と高い值を示し，しかも粒成長が認められず, 鉄粉の製造目的には非常に適したものであることが分かった。

\section{3・5 コークスと粗粒チャー炭の混用による還元反応の検討}

粒度 $-32+80$ meshのコークスと粒度-16 meshのチャー炭を所 定の重量割合と混ぜ,その $5 \mathrm{~g}$ とミルスケールとへマタイトからな る鉄鉱石 $10 \mathrm{~g}$ ならびに石灰石 $1 \mathrm{~g}$ の混合物をマイクロ波照射実験 に供試した。実験結果をFig.12 に示す。図に明らかなように, チャ一炭の混合比が大きいほど還元率は高いが，チャー炭を例え ば重量比で40\% と適当に混合することで高い還元率を得ることが 
Table 4 Reduction of mill scale-hemataite mixture with recycled coal-char.

\begin{tabular}{|c|c|c|c|c|c|c|c|}
\hline \multicolumn{5}{|c|}{ Magnetics in reduced product } & \multicolumn{3}{|c|}{ Non magnetics in reduced product } \\
\hline \multicolumn{2}{|c|}{ Weight } & \multirow{2}{*}{$\begin{array}{l}\mathrm{Fe}_{\mathrm{t}} \\
(\%)\end{array}$} & \multirow{2}{*}{$\begin{array}{l}\mathrm{Fe}_{\mathrm{m}} \\
(\%)\end{array}$} & \multirow{2}{*}{$\begin{array}{l}\text { Reduction } \\
(\%)\end{array}$} & \multicolumn{2}{|c|}{ Weight } & \multirow{2}{*}{$\begin{array}{l}\mathrm{Fe}_{\mathrm{t}} \\
(\%)\end{array}$} \\
\hline (g) & $(\%)$ & & & & (g) & $(\%)$ & \\
\hline 9.0 & 72.0 & 91.34 & 78.74 & 85.3 & 3.5 & 28.0 & 2.41 \\
\hline
\end{tabular}

できるので, 経済面など合わせて, 粒度も考虑し総合的に適量を 決めてやれば混用も可能であろう。しかし，前述の $3 \cdot 4$ において 述べたように，微粉砕したュークスを用いて開放系でマイクロ波 照射を行う方が，技術的には遥かに妙味があり，工業的な検討と してはこちらの方を優先させるべきと考える。

\section{$3 \cdot 6$ 使用済みチャー炭による鉄鉱石の還元実験}

ミルスケールーヘマタイトの混合鉄鉱石 $10 \mathrm{~g}$ を $5 \mathrm{~g}$ のャャ一炭 で還元した場合, 非磁着分として約 $3.5 \mathrm{~g}$ が回収される。その構成 は未反応の鉄鉱石と残余のチャ一炭ならびに石灰石の熱分解生成 物である $\mathrm{CaO}$ から成ると考えられる。したがって照射時間10分後 の還元率から考元，また生成 $\mathrm{CaO}$ 量から考えて，2回の還元実験 で回収した非磁着分を合わせ, 新しい鉄鉱石の還元に再使用した 場合には $5 \mathrm{~g}$ 強の使用済みチャ一炭が確保できることになる。

この 2 回分の回収非磁着物と鉄鉱石（ミルスケールーヘマタイ ト混合鉱 ) $10 \mathrm{~g}$ ならびに石灰石を混合し, マイクロ波照射実験に供 試した。実験結果をTable 4 に示す。この表にみられるように金 属鉄の回収率に従って鉄鉱石の還元率は $85.3 \%$ と高かった。また 得られた磁着物の量は約 $2 \mathrm{~g}$ 多くなっているが, これは非磁着物中 に残っていた鉄鉱石が再度の還元反応により還元されたことに起 因すると考えられる。このことは極めて重要な知見である，すな わち, 過剩のカーボンを用いて急速な昇温速度を得, その結果十 分大きい速度で還元反応を行わせ, 残余のカーボンは磁選におけ る非磁着分として回収して再使用することにより, 非磁着分中に 残った未反応の鉄鉱石をも有効に回収できることを意味している。 もし $\mathrm{CaO}$ の蓄積が問題となる場合には，これを水洗除去した後, 鉄・カーボンの回収を行えばよい。このように, 本方法ではカー ボンの有効利用と金属鉄の高い回収率が期待できる。

\section{4. まと め}

ミルスケールおよびへマタイトの 2 種類の鉄鉱石について, 主 としてチャ一炭と石灰石からなる反応系を選びマイクロ波照射下 で鉄粉製造を目的とした還元実験を行った。さらにチャ一炭以外 の炭素源としてコークス, ホンゲイ炭の適用性についても検討し， 大略次の墸点を明らかにした。

1) チャー炭によるミルスケールの還元速度および50\%還元ま で平均速度はチャ一炭量の増加と共に増加する。一方そのマイク 口波照射 10 分間までの還元率は鉄鉱石に対しチャ一炭添加量が当 量比で約 4 まではほぼ直線的に増加するがそれ以上カーボン量を
増加させても，大きくは増加せず，ほぼ飽和状態に到達する現象 が認められた。

2) チャー炭によるミルスケールとへマタイトの混合鉱石の還 元実験ではミルスケール混合率 $40 \%$ (重量基準) 以下では, 両者 の加成性から予期される還元率を示すのに対し, それ以上のミル スケールの混合により, 加成性から予期される以上の還元率が得 られる。

3) 各種炭素材の粒度を- $32+80$ meshに整粒し, ミルスケール とへマタイトの混合鉱を還元処理した場合には, チャ一炭が最も 大きい還元速度を示すのに対し，コークスのそれは極めて小さい。 しかしコークスを-325 meshに粉砕すると還元速度は大きく改善さ れ，還元により生成された金属鉄は粒状に成長する。大きな還元 速度を確保しながら金属鉄粒子の成長を妨害するための一方法と して微粉碎したコークスとチャー炭の混用が有用である。さらに 微粉碚したコークスを単味で添加する場合には放熱防止策を講ず ることなく開放系で還元を行っても効果的に目的が達成できる。

4) カーボンを過剩に添加した還元反応において反応後磁選に より非磁着分として回収された非磁着分中に残った使用済みカー ボンは還元材として効率よく再使用できる。さらに非磁着分とし て回収された未反応の鉄鉱石はこの再使用により金属鉄に還元さ れるため,フレッシュなカーボンを用いた場合よりむしろ大きい 金属鉄の回収率が得られる。

以上の知見からマイクロ波を利用する鉄粉製造は, 適当なマイ クロ波照射設備を開発すれば, 安価でしかも滞留時間の短い新し い鉄粉製造方法となり得ると考えられる。

謝辞本研究の計画ならびに報文作成に際し, 有益なご助言 を賜った ( 著者らの一人(神野))の学友であられる) 京都大学名 誉教授真嶋宏博士に深く感謝の意を表する。

\section{引用 文 献}

1）酒井 均・神野孝行・武田隆造：マイクロ波を利用する各種酸化鉱 および炭酸塩鉱の炭素還元, 資源と素材, Vol.109, №.8 (1993) に揭載

2) Worner, H.: Inst. Min. Metal1. Pub1. Ser., Vol. 89, No.6, p.17-20, (1989)

3) Standish, N. and Huang, W.: ISIJ Int., Vol.31, p. $241-245,(1991)$

4) Standish, N. and Worner, H. : Iron S teelmaker, Vol.18, No.5, p.59-61, (1991)

5) McGill, S. L., Walkiewrcz, J.W., and Smyers, G. A.: Material Research Society, Vol.127, p. 247-252, (1988) 